ИССЛЕДОВАНИЕ И РАЗРАБОТКА ОПТИМАЛЬНЫХ КОНСТРУКЦИЙ АРМИРОВОК СТВОЛА С КАНАТНО-ПРОФИЛЬНЫМИ ПРОВОДНИКАМИ

${ }^{1}$ Рубель А.А., ${ }^{2}$ Рубель А.В.

${ }^{1}$ ГП «ОК«Укруглереструктуризачия», ${ }^{2}$ Минэнергоуголь Украины

ДОСЛІДЖЕННЯ І РОЗРОБКА ОПТИМАЛЬНИХ КОНСТРУКЦІЙ АРМУВАННЯ СТОВБУРА 3 КАНАТНО-ПРОФІЛЬНЫМИ ПРОВІДНИКАМИ

${ }^{1}$ Рубель А.О., ${ }^{2}$ Рубель О.В.

${ }^{1}$ ДП «ОК«Укрвуглереструктуризачія», ${ }^{2}$ Міненерговугілля Украйни

\title{
RESEARCH AND DEVELOPMENT OF OPTIMUM CONSTRUCTIONS FOR SHAFT EQUIPMENT WITH ROPE-PROFILE GUIDES \\ ${ }^{1}$ Rubel A.A., ${ }^{2}$ Rubel A.V.
}

${ }^{1} S E O K$ «Ukruglerekstrukturizatsiya», ${ }^{2}$ Ministry of Power Engineering and Coal Industry of Ukraine

Аннотация. Вертикальные стволы горных предприятий - основные выработки шахты, которые рассчитаны на весь срок работы шахты и долгое время после прекращения ее эксплуатации. Они оборудуются армировкой с расстрелами и проводниками, в качестве проводников используют рельсовые или коробчатые профили, а также проводниковые и отбойные канаты.

В основу исследования положена задача - поиск и разработка новых канатно-профильных армировок для вертикальных стволов В работе исследованы существующие методы армирования стволов, и разработаны конструктивные решения по армированию ствола на основе канатно-профильных проводников с, элементами их крепления, натяжными устройствами и консольными расстрелами. Разработка данных конструктивных решений для канатно-профильной армировки ствола позволит преодолеть недостатки существующих жестких и гибких армировок и обеспечить: снижение количества проводников и расстрелов, расположенных по глубине ствола; более высокую скорость движения и грузоподъемность сосудов; более длительный безаварийный срок эксплуатации; снижение капитальных затрат вследствие уменьшения диаметра ствола (по фактору армировки для гибких армировок); снижения трудоемкости обслуживания и ремонта; значительное снижение металлоемкости армировки по сравнению с жесткой армировкой стволов; снижение уровня динамических колебаний в системе «сосуд-армировка»; увеличение демпфирующих свойств армировки ствола; снижение аэродинамического сопротивления ствола до уровня гибкой армировки; повышение уровня надежности и безопасности эксплуатации армировки ствола; исключение необходимости применения отбойных канатов; увеличение срока эксплуатации проводников до уровня жесткой армировки ствола. И, как прямое следствие, повышение рентабельности добычи полезных ископаемых с более глубоких горизонтов.

Внедрение канатно-профильных армировок позволит значительно повысить уровень безопасной эксплуатации армировки вертикального ствола и рентабельности подъемного комплекса в целом.

Ключевые слова: шахтные вертикальные стволы, канатно-профильные проводники, скипы, расстрелы, натяжные устройства, канаты.

\section{Постановка проблемы.}

Вертикальные стволы горных предприятий - основные выработки шахты, которые рассчитаны на весь срок работы шахты и долгое время после прекращения ее эксплуатации. Они оборудуются армировкой с расстрелами и проводниками, в качестве проводников используют рельсовые или коробчатые профили, а также проводниковые и отбойные канаты.

С ростом глубины стволов и количества ярусов возникает необходимость в высокой эксплуатационной надежности всех элементов, так как отклонение или выход из строя одного из элементов жесткой армировки приводит к снижению уровня безопасной эксплуатации всей армировки, что может привести к аварии. 
С другой стороны, большое количество ярусов, создает высокое аэродинамическое сопротивление вентиляционной струи по стволу и служит одной из причин перехода на канатные армировки или вызывает необходимость увеличения диаметра ствола.

Жесткая армировка имеет высокую металлоемкость и стоимость, а также требует больших эксплуатационных затрат в течение всего срока службы ствола.

Кроме того, жесткая армировка имеет ряд других существенных недостатков:

- значительные динамические нагрузки в системе «сосуд-армировка» при искривлении проводников»

- значительные объемы работ по заделки расстрелов в крепь ствола и нарушение целостности боковых пород;

- высокое аэродинамическое сопротивление сечения ствола;

- из-за загруженности сечения ствола возникают сложности при спуске негабаритных грузов в шахту;

- высокая трудоемкость изготовления и монтажа и обслуживания элементов армировки.

Гибкая армировка менее широко применяется в стволах и состоит из гибких проводников, выполненных стальными канатами, натяжение которых осуществляется с помощью грузов, которые закрепленных внизу или вверху с помощью коушей и имеет также отбойные канаты.

Гибкая армировка имеет следующие недостатки:

- требуется большее поперечное сечение ствола при тех же параметрах подъема по сравнению с жесткой армировкой, как минимум на 600мм по диаметру;

- низкий срок службы канатных проводников (4года);

- высокая стоимость канатов закрытой конструкции;

- высокий уровень горизонтального раскачивания сосудов под действием сил кручения, возникающих при работе головных канатов, и действия аэродинамических сил при движении сосудов;

- невозможность ремонта отдельных частей канатного проводника;

- большое количество проводниковых и отбойных канатов в стволе;

- большие размеры зумпфовой части ствола для крепления натяжных грузов и обслуживания прицепных устройств;

- наличие жесткой армировки на промежуточных горизонтах и вверху ствола;

- потери рабочего времени связанные с необходимостью замены канатных проводников ствола.

Канатно-профильная армировка [8], представляет собой альтернативное конструктивное решение, позволяющие объединить преимущества жесткой (коробчатые проводники - профиль) и гибкой армировки (канаты) исключив при этом ряд свойственных им недостатков. 
Цель исследований - в основу исследования положена задача - поиск и разработка новых канатно-профильных армировок для вертикальных стволов, которые позволили преодолеть выше приведенные недостатки и позволили бы обеспечить:

- снижения количество проводников и расстрелов, расположенных по глубине ствола;

- более высокую скорость движения и грузоподъемность сосудов;

- более длительный безаварийный срок эксплуатации;

- снижение капитальных затрат при строительстве, вследствие снижения диаметра ствола по сравнению с канатной армировкой;

- снижение трудоемкости обслуживания и эксплуатации;

- значительное снижение металлоемкости армировки по сравнению с жесткой армировкой стволов;

- снижение уровня динамических колебаний в системе «сосуд-армировка»;

- увеличение демпфирующих свойств армировки ствола;

- снижение аэродинамического сопротивления ствола до уровня гибкой армировки;

- повышение уровня надежности и безопасности эксплуатации армировки ствола;

- избавление от отбойных канатов;

- увеличение срока эксплуатации проводников до уровня жесткой армировки ствола.

И, как прямое следствие, снижение капитальных и эксплуатационных затрат при добыче полезных ископаемых с более глубоких горизонтов.

Материалы и результаты исследования.

Канатно-профильная армировка (далее армировка или КПА) ствола состоит из основных элементов, представленных на рис. 1.

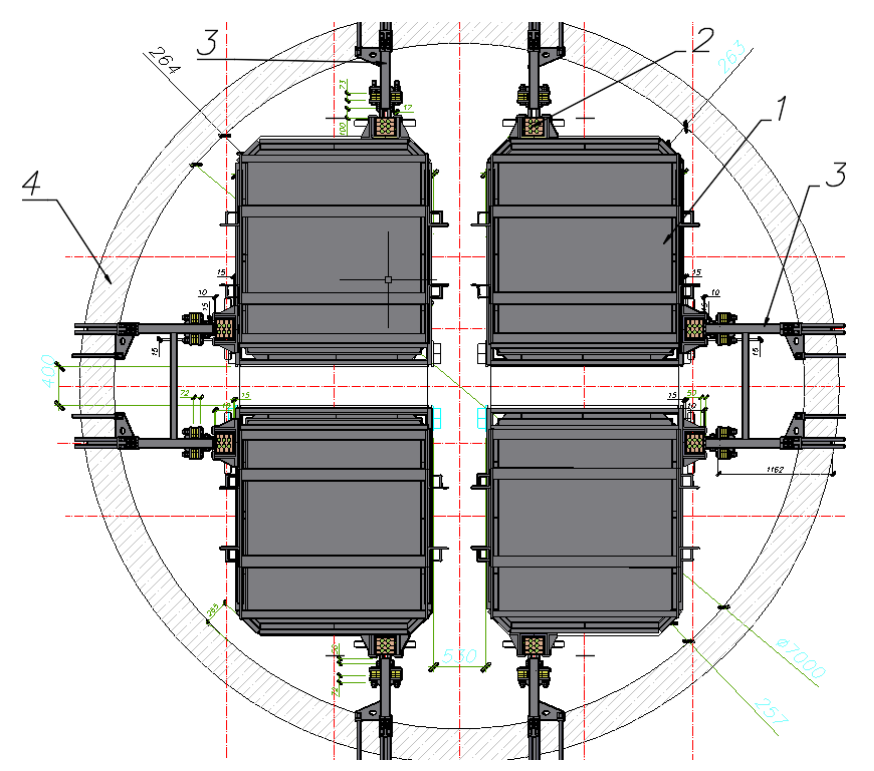

Рисунок 1 - Сечение вертикального шахтного ствола с 2-мя проводниками на сосуд: 1 - подъемный сосуд; 2 - канатно-профильный проводник; 3 - консольно-демпфирующий расстрел; 4 - крепь ствола 
Они расположены в сечении ствола для диаметра ф7000мм с подъемом, оборудованным четырьмя угольны-ми скипами 1СН35-2 - 1, (при схеме армирования 2 проводника на сосуд), дви-жущийся в канатно-профильных проводниках 2, закрепленных в консольно-демпфирующих расстрелах 3 (далее КДР или расстрелы), которые анкерно за-креплены в бетонную крепь ствола 4, причем смежные КДР соединены между собой вставками для увеличения их жесткости.

Движение сосуда осуществляется в канатно-профильных проводниках (далее КПП или проводник), конструкция которого представлена на рис. 2, состоящих из 6-ти стальных канатов типа 42-Г-1-Н-1372 со стальным сердечником ГОСТ 7669-80 ф42мм - поз. 2.1 (для меньших типоразмеров сосудов применяются другие параметры КПП), ограждающего профиля выполненного из гнуто-го швеллера ГОСТ 8278-83 - поз. 2, стыковочной скобы крепления секций, ограждающего профиля между собой 2.2 и промежуточной скобы 2.2 канатов и ограждающего профиля, задняя пластина снята для наглядности.

Проводник изготавливается из гнутых швеллеров $\mathrm{L}=12 \mathrm{M}$, стыковка их между собой осуществляется при помощи специального стыковочного узла, крепление их на проводниковых канатах с помощью канатной скобы крепления 2 (рис. 3). Расстояние между скобами составляет 4 м, причем стыковые скобы длиннее и имеют 4 крепления канатов к ограждающему профилю, промежуточные - короче и имеют 2 крепления. Крепление прицепных устройств верхних концов канатов КПП осуществляется на перекрытии или специально усиленном поясе копра, исключая возможность крепления всех канатов в одном сечении копра.

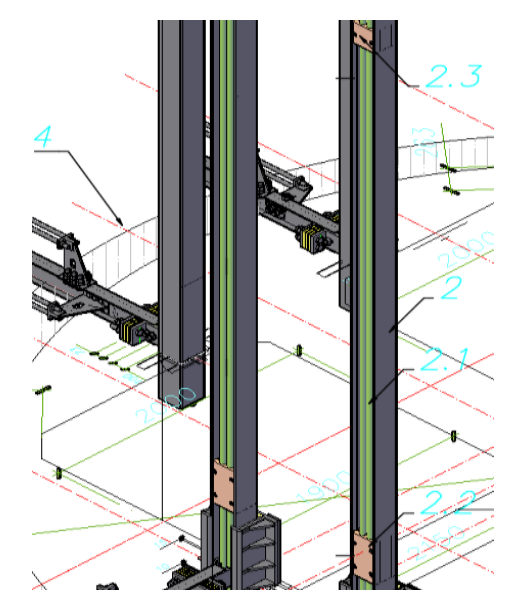

2 - канатно-профильный проводник; 2.1 - канаты; 2.2 - стыковая скоба; 2.3 - промежуточная скоба; 2.4 - задняя крышка проводника; 4 - крепь ствола

Рисунок 2 - Конструкция канатно-профильного проводника

На рис. 3 изображена конструкция проводника разрез, где 2 - ограждающий профиль; 2.1 - стальные канаты; 2.5 - задняя часть скобы, приваренная сваркой к ограждающему профилю; 2.6 - промежуточные стяжные части скобы; 2.7 - 
крайняя часть скобы; 2.8 - стягующие шпильки частей скобы канатов и профиля в единую конструкцию.

Передача горизонтальных динамических нагрузок от движущихся сосудов в лобовых и боковых направлениях на канатно-профильные проводники осуществляется при помощи роликов качения типа НКП (и их модификаций) и предохранительных лап с захватами 5 (рис. 2, 3, 4), которые обеспечивают при этом надежную кинематическую связь сосуда и проводников в соответствии с регламентируемыми ПБ зазорами.

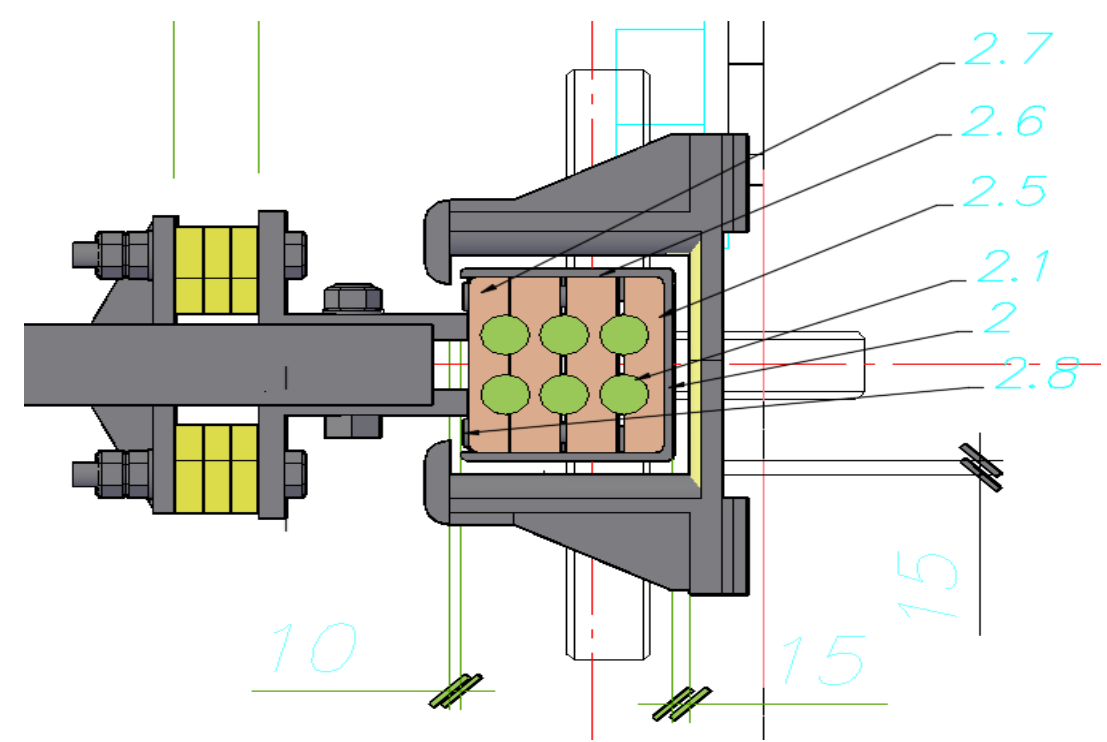

2 - канатно-профильный проводник; 2.1 - канаты; 2.5 - задняя часть скобы;

2.6 - промежуточные стяжные части скобы; 2.7 - крайняя часть скобы;

2.8 - стягивающие шпильки

Рисунок 3 - Конструкция канатно-профильного проводника. Вид сверху

При этом движение, в основном осуществляется в роликовых направляющих имеющих большую жесткость, чем проводник, изгибая его и демпфируя нагрузку за счет канатов проводника и резины роликов, поэтому контакта и истирания лапами проводников не происходит, что обеспечивает долговечность ограждающего профиля проводника.

Канатно-профильный проводник воспринимает горизонтальные динамические нагрузки от сосуда и демпфирует их за счет растяжения канатов двух КПП и далее передает остальную часть нагрузки на консольнодемпфирующие расстрелы с помощью подвижной скобы крепления 3.4 (рис. 4). Подвижная скоба закреплена на расстреле и проводник может двигаться вверхвниз относительно скобы, а сама скоба может перемещаться в горизонтальной плоскости влево-вправо, вперед-назад передавая, таким образом, горизонтальную динамическую нагрузку, в лобовом и боковом направлениях, от проводника к расстрелу. Задняя крышка на данном участке между двумя скобами крепления отсутствует. При этом при деформации крепи ствола под горным давлением или искривления расстрелов не изменяется вертикальность отвеса проводников в стволе. 


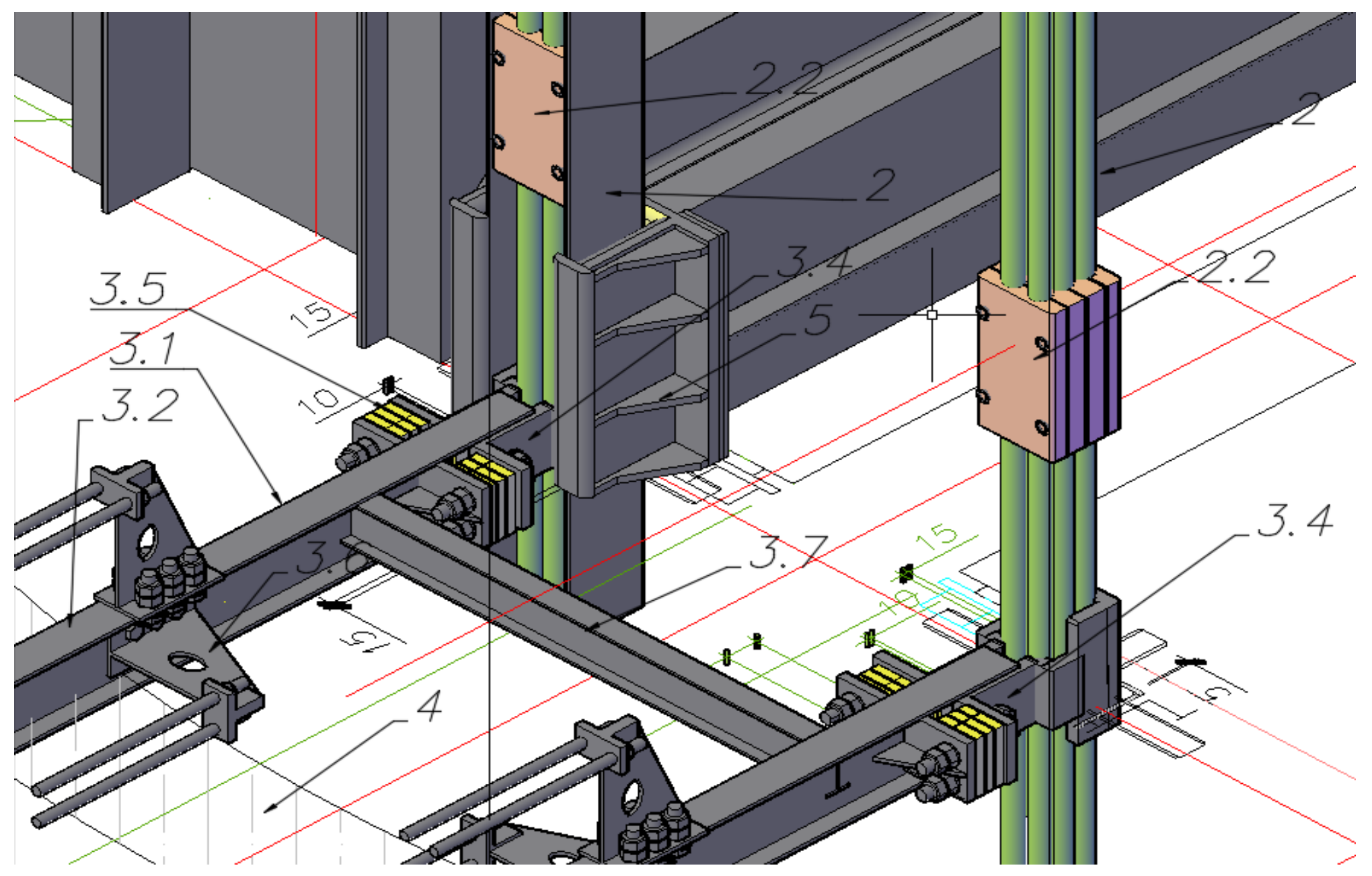

2 - канатно-профильный проводник; 2.1 - канаты; 2.2 - стыковая скоба; 3.1 - консольный расстрел; 3.2 - часть расстрела, заделываемая в крепь ствола; 3.3 - анкера крепления; 3.4 - подвижная скоба крепления; 3.5.1 - демпфера для лобовых колебаний; 3.5.2 - демпфера для боковых колебаний; 3.7 - 4 - крепь ствола; 5 - предохранительная лапа с захватами

Рисунок 4 - Конструкция консольно-демпфирующего расстрела 
На рис. 4 изображена конструкция консольно-демпфирующего расстрела, с креплением его к проводнику (для наглядности сняты ограждающий профиль одного проводника и задние ограждающие крышки), где 3.1 - консольный расстрел, выполненный из двутавровой или коробчатой балки; 3.2 - часть расстрела заделываемого в крепь ствола; 3.3 - анкерное крепление к крепи ствола (металлическое или канатное); 3.4 - соединительная подвижная скоба; 3.5 .1 - пакет демпфирующих вставок в лобовом направлении; 3.5.2 - пакет демпфирующих вставок в боковом направлении; 3.6 - упоры консольного расстрела в крепь ствола; 3.7 - распоры между смежными консольными расстрелами; 4 крепь ствола; 5 - предохранительная лапа сосуда с захватом;

Пакеты демпфирующих вставок, воспринимающие горизонтальную нагрузку от движущего сосуда, через соединительную скобу, выполняются из пластин резины с расположенными между ними металлическими пластинами, первые резиновые пластины имеют меньшую жесткость до 10кН и высокую податливость, для предоставления возможности изгибаться КПП, и далее жесткость резиновых пластин ступенчато увеличивается для демпфирования значительных динамических усилий до 75 кН.Консольно-демпфирующие расстрелы, образующие ярус, расположены с шагом 60 м и более по глубине ствола, в месте встречи сосудов одного подъема шаг становится дискретным [6] (рис 5).

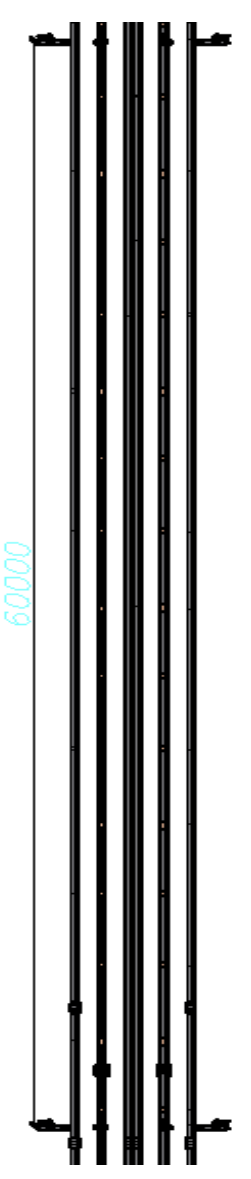

a

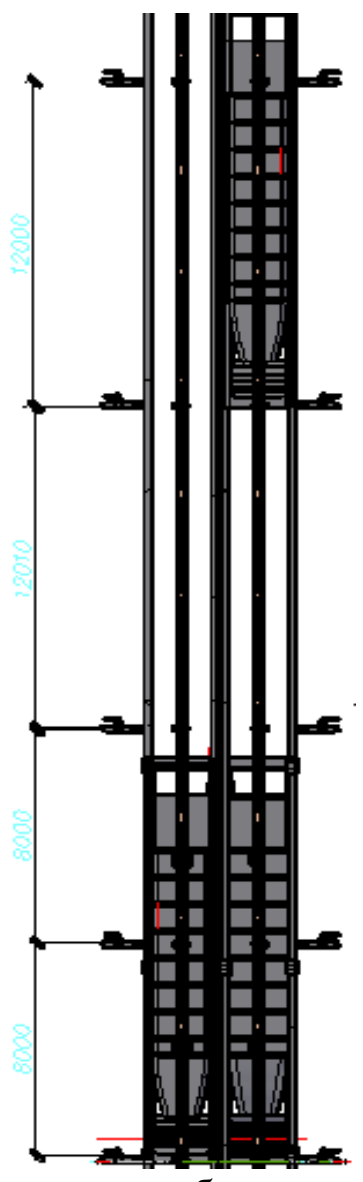

6

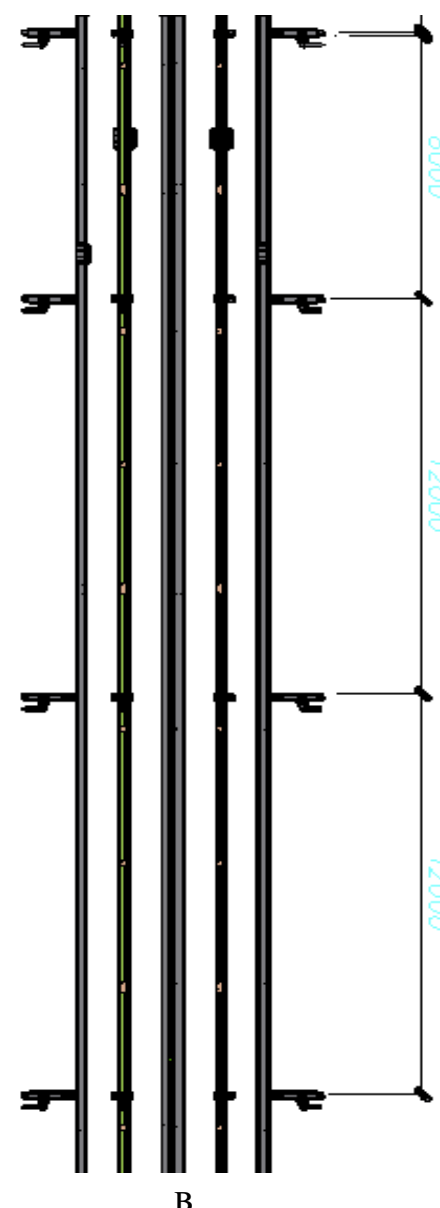

B

a - по длине ствола; б - в месте встречи сосудов в середине ствола (в начале); в - в месте встречи сосудов в середине ствола (в конце);

Рисунок 5 - Дискретное расположение консольных ярусов по глубине ствола 
Сначала два пролета имеют шаг 12м потом, непосредственно в месте встречи сосудов, три пролета имеют шаг 8 м и далее шаг увеличивается до $12 \mathrm{M}$ и далее увеличивается до 60 м и более.

Такое расположение ярусов позволяет значительно снизить динамические колебания в месте встречи сосудов, возникающие в системе «сосуд-армировка» из-за эксцентриситета загрузки сосудов, неравномерности натяжения канатов, кручения канатов, в режимах предохранительного торможения, аварийного торможения, колебания уравновешивающих канатов, влияния параметров рабочей диаграммы скорости, влияния радиусов желобов скипа, искривления профилей и прочих негативных факторов.

Конструкция разработанного натяжного устройства [7] представлена на рис. 6 и имеет значительно меньшую массу и габариты, по сравнению с натяжными грузами для гибкой канатной армировки, так как часть натяжения осуществляется за счет веса ограждающего профиля КПП.

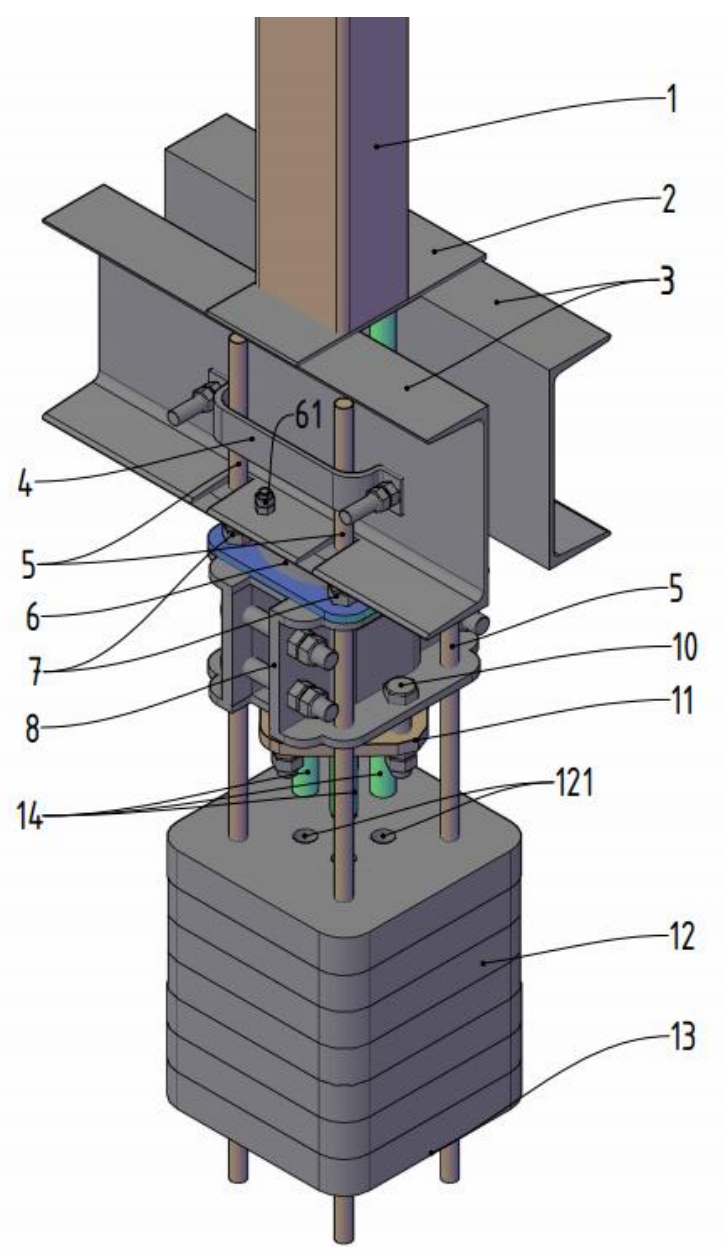

1 - канатно-профильный проводник; 2 - опорная планка; 3 - горизонтальные швеллеры (балки, «опорный стул»); 4 - ограничивающая скоба; 5 - направляющие стержни натяжной рамы; 6 - демпферный блок; 61 - крепление верхней части демпферного блока 6 к низу швеллеров; 7 - болтовое крепление; 8 - натяжной блок; 9 - цанговые крепления кантов; 10 - болтовое соединение; 11 - стяжная планка цангового крепления 9; 12 - натяжной груз; 13 - планка крепления грузов; 14 - канаты

Рисунок 6 - Натяжное устройство канатно-профильных проводников 
Натяжное устройство может двигается по направляющим 5 вверх-вниз и демпфирует колебания за счет растягивания канатов. Внизу к направляющим 5 закреплены натяжные грузы 12, натяжной блок 8, демпферный блок 7, а верхний конец направляющих, закреплён ограничивающей скобкой 4. Сверху находится КПП, канаты 14 которого проходят через швеллеры и закреплены в натяжном блоке (рис.7) с помощью цангового крепления 9. Снизу всю конструкцию натягивают грузы 12. Натяжной блок имеет разборную на три части конструкцию, в вертикальном направлении соединенную болтовым соединением 10. Снизу стяжной пластиной 11 цанги с канатами зажимаются в конусных отверстиях в натяжном блоке.

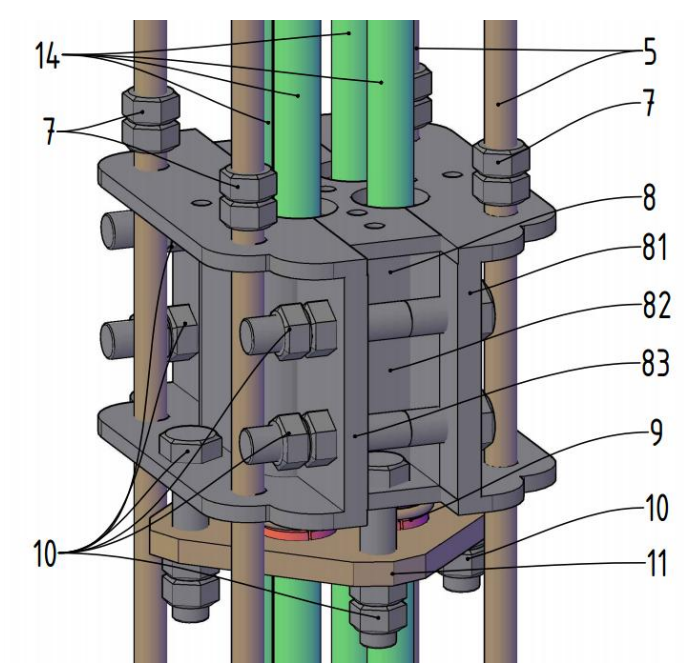

5 - направляющие стержни; 8 - натяжной блок; 9 - цанговые крепления канатов; 10 - болтовое соединение; 11 - стягующая планка цангового крепления; 14 - канаты

Рисунок 7 - Натяжной блок

Демпфирующий блок (рис. 8) расположен между натяжным блоком 8 и швеллерами, верхняя часть 62 прикреплена до швеллера болтами 61 между ними расположены резиновые пластины, которые разделены металлическими пластинами.

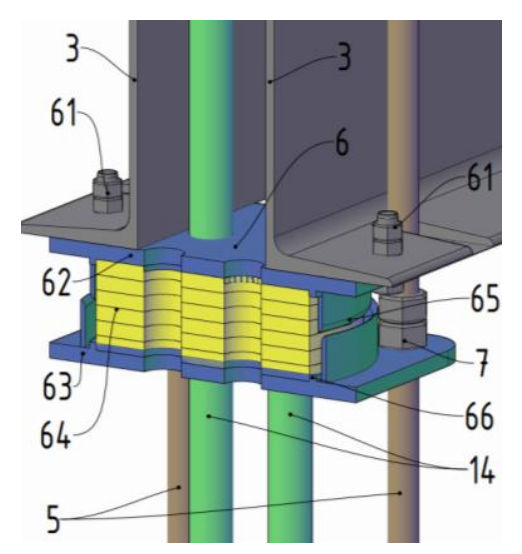

5 - направляющие стрежни; 6 - демпферный блок; 61 - крепление верхней части демпферного устройства; 62 - верхняя часть блока; 63 - нижняя часть блока; 64 - резиновые пластины; 65 - фаски; 66 - ограничивающий выступ; 10 - болтовое соединение; 14 - канаты

Рисунок 8 - Демпфирующий блок 
По методике [1] п.2.5.1. канатные проводники и отбойные канаты должны быть постоянно натянуты при помощи натяжных грузов.

Ниже приведена методика определения массы грузов для натяжения канатных проводников и КПП в нижнем его сечении ствола имеют величину не ниже значения, определяемого по формуле (2.5.2) [1]

$$
Q_{\text {raT. }}=A\left(L_{0}-L\right) \ln \frac{L_{0}}{L_{0}-L}, \mathrm{H}
$$

где $A$ - минимальный коэффициент сопротивления канатного проводника поперечным отклоняющим усилиям, $\mathrm{H} / \mathrm{M} ; A=125 \mathrm{H} / \mathrm{M} ; L_{0^{-}}$предельная длина канатного проводника, м; $L$ - длина отвеса канатного проводника, м.

Предельная длина канатного проводника определяется по формуле

$$
L_{0}=\frac{G_{B}}{n \gamma}, M
$$

где $G_{B}$ - расчетное временное сопротивление разрыву проволок, МПа; $n$ - запас прочности каната; $\gamma$ - объемный вес каната, $\mathrm{H} / \mathrm{M}^{3}$.

Объемный вес каната определяется из выражения $\gamma=\frac{P}{S}$, где $P$ - вес одного метра смазанного каната, H/м; $S$ - площадь поперечного сечения всех проволок каната, м $^{2}$.

Расчетный запас прочности принятого каната

$$
n_{\text {申.c. }}=\frac{Q_{\text {pasp. }}}{Q_{\text {нaт.min .c. }}+Q_{\text {кан.c. }}},
$$

где $Q_{\text {разр }}, \mathrm{H}$ - суммарное разрывное усилие всех проволок в канате; $Q_{\text {кан.с. }}=L_{c} \cdot \rho_{\Pi}$.

Расчетный запас прочности проводникового каната, превышающий допустимый $n=6$, дает возможность увеличить натяжение каната в нижнем его сечении, что уменьшает величину угловых перемещении сосудов. Величина этого натяжения определяется из выражения

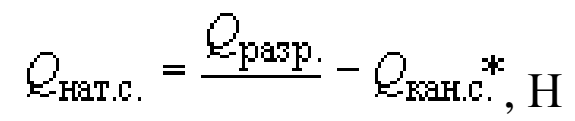

Масса натяжного груза одного каната:

$$
Q_{\text {гр.с. }}=0,102 \cdot Q_{\text {нат.c. }}, \text { кг. }
$$

Масса натяжного груза одного КПП

$$
Q_{\text {гp.кnn }}=Q_{\text {гp.c. }} * N-Q_{\text {oгp.np }}
$$


где $N$ - количество канатов в КПП, шт; $Q_{o г p . n p}$-масса ограждающего профиля, КГ

Результаты расчетов натяжения КПП и канатов гибкой армировки сведены в табл. 1.

Таблица 1 - Сравнительный вес натяжных грузов КПП и гибкой армировки

\begin{tabular}{|c|c|c|c|c|}
\hline $\begin{array}{c}\text { Обозна } \\
\text { чение }\end{array}$ & Наименование & Ед. изм & $\begin{array}{c}\text { Гибкая } \\
\text { армировка } 1 \\
\text { канат ф52 }\end{array}$ & $\begin{array}{c}\text { КПП } \\
6 \text { канатов } \\
\text { ф42 }\end{array}$ \\
\hline & ГОСТ & & $7669-80$ & $7669-80$ \\
\hline & Сечение ограждающего профиля проводника & MM & & $200 \times 180 x 6$ \\
\hline & Диаметр канатов проводника & MM & 52,00 & 42 \\
\hline & Тип канатов & & $\begin{array}{c}52,0-\Gamma-1-\mathrm{H}- \\
1372\end{array}$ & $\begin{array}{l}42,0-\Gamma-1-\mathrm{H}- \\
1372\end{array}$ \\
\hline & Количество проводников канатов & шт & 16,00 & 48,00 \\
\hline & Количество отбойных канатов & шт & 6,00 & \\
\hline & Натяжение проводника & $\mathrm{H}$ & 111806,47 & 78712,82 \\
\hline$A$ & $\begin{array}{llr}\text { Минимальный } & \text { коэффициент } & \text { сопротивления } \\
\text { канатного } & \text { проводника } & \text { поперечным } \\
\text { отклоняющим усилиям } & \end{array}$ & $\mathrm{H} \backslash \mathrm{M}$ & 125,00 & 125,00 \\
\hline Lo & предельная длина канатного проводника & M & 2566,20 & 1781,07 \\
\hline$L$ & длина отвеса канатного проводника & M & 1300,00 & 1300,00 \\
\hline$G_{B}$ & $\begin{array}{l}\text { расчетное временное сопротивление разрыву } \\
\text { проволок }\end{array}$ & МПа & 1372,00 & 989,50 \\
\hline & запас прочности каната & & 6,00 & 6,00 \\
\hline$\gamma=\frac{P}{S}$ & $\begin{array}{lllll}\text { Объемный } & \text { вес } & \text { каната } & \text { определяется } & \text { из } \\
\text { выражения } & & & & \end{array}$ & $\mathrm{H} / \mathrm{M} 3$ & 89107,01 & 92593,91 \\
\hline$P$ & вес одного метра смазанного каната & $\mathrm{H} / \mathrm{M}$ & 116,2 & 78,14 \\
\hline$S$ & $\begin{array}{l}\text { Площадь поперечного сечения всех проволок } \\
\text { каната }\end{array}$ & $\mathrm{M}^{2} 10-6$ & 1304,05 & 843,90 \\
\hline$n$ & Расчетный запас прочности принятого каната & & 6,79 & 6,41 \\
\hline$Q_{\text {разр }}$ & $\begin{array}{l}\text { Суммарное разрывное усилие всех проволочек } \\
\text { в канате }\end{array}$ & $\mathrm{H}$ & 1785000,00 & $\begin{array}{c}1155 \\
000,00\end{array}$ \\
\hline$Q_{\text {кан.с }}$ & Вес смазанного каната & $\mathrm{H}$ & 151060,00 & 101582,00 \\
\hline$Q_{\text {Ham.c }}$ & $\begin{array}{lrll}\text { Величина дополнительного } & \text { натяжения } & \text { с } \\
\text { учетом расчетного запаса } n=6 & & \end{array}$ & $\mathrm{H}$ & 146440,00 & 90918,00 \\
\hline$Q_{2 p . c}$ & Масса натяжного груза для одного каната & кГ & 14936,88 & 9273,64 \\
\hline$Q_{\text {orp.np }}$ & Масса ограждающего короба одного КПП & КГ & & 39429,00 \\
\hline \multirow[t]{3}{*}{$Q_{2 p . \kappa n n}$} & $\begin{array}{l}\text { Масса натяжного груза КПП (6 канатов по } \\
\text { ф42) }\end{array}$ & кГ & & 16212,82 \\
\hline & Количество натяжных грузов в зумпфе & & 22,00 & 8,00 \\
\hline & Общая масса натяжных грузов в зумпфе & & 328611,36 & 129702,53 \\
\hline
\end{tabular}


Как видно из приведенных расчетов в табл.1, при применении КПП и демпфирующего натяжного устройства для одних и тех же параметров подъема и схемы армировки (рис. 1) количество грузов в стволе сократилось в 2.75 раза, а масса грузов в зумпфе сократилась в 2.5 раза, при этом вес грузов может располагаться по горизонтали, а не по вертикали, как для гибкой армировки.

Натяжное устройство закрепляет канаты КПП проводника, демпфирует колебания, возникающие в канатах КПП, снижает раскачивание сосудов в стволе, и значительно уменьшает глубину зумпфа и количество оборудования в нем.

Исследованиями [3] установлено, что уровень горизонтальных динамических нагрузок до 10кН в жесткой армировки соответствует безударному проектному режиму.

Определим значения лобовых прогибов проводников для гибкой армировки и КПП при приложении статической нагрузки 10кН, результаты жесткости были получены с помощью метода конечных элементов в программе ANSYS 17.1 и сведены в табл. 2. Также были определены моменты сопротивления вращению сосудов в системе «сосуд-гибкая армировка» по формуле (4.1), (4.2), (4.3) [1] и определены величины угловых перемещений сосудов по формулам (4.6), (4.7) с учетом принятых коэффициента динамичности $K_{\partial}=1,5$ и коэффициента безопасности $K_{\sigma}=5$ согласно [1] результаты расчетов сведены в табл. 2.

Таблица 2 - Сравнительная таблица определения прогибов при приложении статической горизонтальной нагрузки 10кН

\begin{tabular}{|c|l|c|c|c|}
\hline $\begin{array}{c}\text { № } \\
\text { ㄱ }\end{array}$ & \multicolumn{1}{|c|}{ Наименование } & Ед. изм. & $\begin{array}{c}\text { 4 канатных } \\
\text { прока ф52 }\end{array}$ & $\begin{array}{c}\text { 2 КПП на } \\
\text { сосуд (6x ф42) }\end{array}$ \\
\hline 1 & $\begin{array}{l}\text { Прогиб канатного проводника в середине } \\
\text { ствола }\end{array}$ & мм & 917,25 & \\
\hline 2 & $\begin{array}{l}\text { Гарантированный зазор между сосудами } \\
\text { Г }\end{array}$ & мм & 50 & 50 \\
\hline 3 & Угол поворота груженого сосуда & град & 2,7 & 0,0260 \\
\hline 4 & Угол поворота порожнего сосуда & град & 1,7 & 0,0260 \\
\hline 5 & Коэффициент динамичности Кд & & 1,5 & 1,5 \\
\hline 6 & Коэффициент безопасности Кб & & 5 & 5 \\
\hline 7 & Итого угол поворота груженого сосуда & & 20,25 & 0,195 \\
\hline 8 & Итого угол поворота порожнего сосуда & & 2,55 & 0,039 \\
\hline 9 & Прогиб проводника при шаге 8м & мм & & 4 \\
\hline 10 & Прогиб проводника при шаге 12м & мм & & 7,6 \\
\hline 11 & Прогиб проводника при шаге 60м & мм & & 47 \\
\hline
\end{tabular}

Как видно из табл. 2, углы поворота сосудов в проводниках КПП во много раз меньше, чем для гибких проводников (канатов), что очевидно ведь жест- 
кость ограждающего короба на кручение намного больше, чем каната, причем в данном случае не учитывалось влияние консольных расстрелов на снижение кручения ввиду достижения итак малых значений.

Прогиб проводников в лобовом направлении под статической нагрузкой 10 кН для гибких проводников составляет 917 мм, а для КПП в месте встречи сосудов - 4 мм при шаге 8 м, далее при разминовке сосудов шаг увеличился до 12 м прогиб составил - 7,6 мм, данные прогибы гасится за счет растяжения канатов. При движении по стволу сосуд может выгибать проводники под статической нагрузкой в середине пролета при шаге 60 м до 47 мм, в данном случае, она демпфируется за счет изгиба КПП и демпфирования ее на четырех (два внизу, два вверху см. схему рис. 1) консольно-демпфирующих расстрелах.

Исследованиями [3] на основании многочисленных данных для жесткой армировки установлено, что при небольших эксцентриситетах груза в сосуде дополнительные нагрузки составляют 25кН, а при значительных смещениях груза сильно возрастают и достигают 60-70кН, результаты прогибов проводников при приложении статической нагрузки 60кН, полученных методом конечных элементов в программе ANSYS 17.1 сведены в табл. 3.

Таблица 3 - Определения прогибов при приложении статической горизонтальной нагрузки $60 \kappa \mathrm{H}$

\begin{tabular}{|c|l|c|c|c|}
\hline $\begin{array}{c}\text { № } \\
\text { пІп }\end{array}$ & \multicolumn{1}{|c|}{ Наименование } & Ед.изм & $\begin{array}{c}\text { 4 канатных } \\
\text { прока ф52 }\end{array}$ & $\begin{array}{c}2 \text { КПП на } \\
\text { сосуд (6x } \\
\text { ф42 })\end{array}$ \\
\hline 1 & $\begin{array}{l}\text { Прогиб канатного проводника в } \\
\text { середине ствола }\end{array}$ & мм & 4588 & \\
\hline 2 & $\begin{array}{l}\text { Угол поворота груженого сосуда от } \\
\text { кручения подъемных канатов }\end{array}$ & град & 2,7 & 0,0260 \\
\hline 3 & $\begin{array}{l}\text { Угол поворота порожнего сосуда от } \\
\text { кручения подъемных канатов }\end{array}$ & град & 1,7 & 0,0260 \\
\hline 4 & Коэффициент динамичности Кд & & 1,5 & 1,5 \\
\hline 5 & Коэффициент безопасности Кб & & 5 & 5 \\
\hline 6 & Итого угол поворота груженого сосуда & & 20,25 & 0,195 \\
\hline 7 & Итого угол поворота порожнего сосуда & & 2,55 & 0,039 \\
\hline 8 & Прогиб проводника при шаге 8м & мм & & 24 \\
\hline 9 & Прогиб проводника при шаге 12м & мм & & 45,6 \\
\hline 10 & Прогиб проводника при шаге 60м & мм & & 282 \\
\hline
\end{tabular}

Как видно из приведенных результатов расчета (табл. 3), прогиб в месте встречи сосудов при шаге 8 м составляет 24 мм, при 12 м - 45,6 мм, что позволяет сосудам безопасно разъезжаться в стволе, так как прогиб КПП в середине ствола не критичен и имеется большее количество КДР которые 
активно демпфируют горизонтальную нагрузку за счет демпферов, имеющих 3 ступени жесткости.

При шаге между ярусами 60м статический прогиб в середине ствола составляет 282 мм, из них 10 кН демпфирует проводники, 20 кН демпфирует 4 роликовых направляющих сосуда типа НКП, остальную нагрузку 30 кН демпфируют четыре расстрела, позволяя проводнику изгибаться.

Статический прогиб 4 канатных проводников 52,0-Г-1-Н-1372 со стальным сердечником по ГОСТ 7669-80 при приложении горизонтальной нагрузки 10кН составляет 917,25 мм, а при 60 кН прогиб составляет 4588 мм. Раскачивание сосудов при их движении в стволе по проводникам с прогибом 917,25 мм, возникающим при приложении статического горизонтального усилия 10 кН демпфируется отбойными канатами, что приводит к раскачиванию всей гибкой армировки, поэтому при проектировании закладывается увеличение диаметра ствола в виде предохранительных зазоров по 350мм на сторону при глубине ствола свыше 800 м согласно п. 2.2.1. [1].

Раскачивание сосудов при их движении в стволе по канатным проводникам с прогибом 4588 мм, возникающим при приложении статического горизонтального усилия 60 кН демпфированием отбойными канатами, и предохранительными зазорами по 350 мм на сторону погасить крайне трудно, и, исходя из опыта эксплуатации, такие раскачивания наблюдаются крайне редко, и приводят к возникновению аварий, что имеет место быть не так часто.

T.e. такие значительные горизонтальные усилия возникают при высокой жесткости системы «сосуд-армировка», при полном отсутствии податливости проводников и расстрелов, низком значении демпфирования системы, высоких искривлений армировки, влияния горного давления или неправильной эксплуатации.

Кроме того, статические усилия прогибов проводников будут меньше динамических, т.к. в такой гибкой системе резонансные режимы работы в лобовом направлении не наблюдаются из-за большого шага ярусов, гибкости проводников, податливости на консольном ярусе, высокой степени демпфирования, за счет специально разработанных конструкций, всей системы «сосуд-армировка».

Как видно из приведенных расчетов, система КПА обладает многократно высоким запасом устойчивости, надежности эксплуатации и может нормально эксплуатироваться при возникновении аварийных горизонтальных нагрузок в стволе 60-75кН и большом количестве циклов подъема 300раз/день и более.

Между смежными подъемными установками согласно [1] необходимо устанавливать отбойные канаты, в данной КПА они не устанавливаются, так как для повышения уровня безопасной эксплуатации устанавливаются перемычки между консольными расстрелами (рис. 1).

Рассмотрим металлоемкость различных типов армировок при равных параметрах подъема, результаты сведены в табл. 4. 
Таблица 4 - Сравнительная таблица металлоемкости армировок

\begin{tabular}{|c|c|c|c|c|c|}
\hline $\begin{array}{l}\text { № } \\
\Pi / \Pi\end{array}$ & Наименование & $\begin{array}{l}\text { Ед. } \\
\text { изм. }\end{array}$ & $\begin{array}{c}\text { Жесткая } \\
\text { армировка }\end{array}$ & $\begin{array}{c}\text { Гибкая } \\
\text { армировка } 16 \\
\text { канатов ф52 }\end{array}$ & КПП и КДР \\
\hline & Расстрелы & & & & \\
\hline 1 & Глубина ствола & M & 1200,00 & 1200,00 & 1200,00 \\
\hline 2 & Тип расстрела & & $\begin{array}{c}\text { коробчатая } \\
\text { балка }\end{array}$ & & КДР \\
\hline 3 & ГОСТ & & 8509-06 & $7669-80$ & $\begin{array}{l}7669-80 \\
26020-83\end{array}$ \\
\hline 4 & Сечение расстрела & MM & $200 \times 200 \times 14$ & & $160 \times 80 \times 5 \times 7,4$ \\
\hline 5 & Масса расстрела & кг/м.п. & 85,60 & & 15,8 \\
\hline 6 & Длина расстрелов в ярусе & м.П. & 24 & & 3,2 \\
\hline 7 & Шаг армировки & $\mathrm{M}$ & 4,1 & & 60 \\
\hline 8 & Количество ярусов & ШТ. & 292,68 & & 27 \\
\hline & Масса расстрелов ствола & $\mathrm{T}$ & 601,29 & & 1,37 \\
\hline & Проводники & & & & \\
\hline 1 & Сечение проводника & MM & $200 \times 200 \times 14$ & & $200 \times 180 \times 6$ \\
\hline 2 & Масса проводника & кг/м.п. & 85,60 & 23,70 & 77,12 \\
\hline 3 & Длина проводника & м.П. & 1200,00 & 1200,00 & 1200,00 \\
\hline 4 & Масса отбойных канатов & & & 11,85 & \\
\hline 5 & $\begin{array}{l}\text { Количество проводников } \\
\text { и отбойных канатов }\end{array}$ & шт & 8,00 & 22,00 & 8,00 \\
\hline & $\begin{array}{l}\text { Масса проводников } \\
\text { ствола }\end{array}$ & $\mathrm{T}$ & 821,76 & 625,68 & 740,35 \\
\hline & Крепления & & & & \\
\hline 1 & Масса крепления & кГ/шт. & 9,00 & & 48,00 \\
\hline 2 & $\begin{array}{l}\text { Количество креплений в } \\
\text { ярусе }\end{array}$ & шт. & 16,00 & & 8,00 \\
\hline 3 & $\begin{array}{l}\text { Количество креплений в } \\
\text { стволе }\end{array}$ & шт. & 4682,93 & & 160,00 \\
\hline & Масса креплений ствола & $\mathbf{T}$ & 42,15 & & 7,68 \\
\hline \multicolumn{2}{|c|}{$\begin{array}{l}\text { Итого масса армировки } \\
\text { ствола: }\end{array}$} & $\mathbf{T}$ & 1465,19 & 625,68 & 749,40 \\
\hline
\end{tabular}

Как видно из приведенных результатов расчета металлоемкости армировок сведенных в табл.3 КПА имеют меньшую металлоемкость по сравнению с жесткой почти в 2 раза, и только на 16.5 \% превышают по металлоемкости гибкую армировку (за счет отсутствия отбойных канатов). При этом суммарное сечение всех канатов в КПА, по которым двигаются сосуды превышает суммарное сечение всех проводниковых канатов гибкой армировки в 2 раза (кроме отбойных канатов, по ним сосуды не двигаются), т.е. имеет существенных запас прочности, что еще раз подтверждает высокую надежность и низкую металлоёмкость армировки с канатно-профильными проводниками при значительном количестве циклов подъема 300 разไдень и более. 


\section{Выводы.}

Разработка конструкций новых канатно-профильных армировок (КПА) для вертикальных стволов, позволит преодолеть выше приведенные недостатки присущие гибким и жестким армировкам и обеспечить:

- достижение более высоких значений скоростей движения до 16 мlс и грузоподъемности сосудов;

- увеличение срока эксплуатации канатов до 15 лет, больше чем для гибких армировок (замена канатов через 4-6 лет);

- более долгий срок службы всей армировки в сравнении с жесткой армировкой;

- снижение капитальных затрат вследствие уменьшения диаметра ствола на 500-600мм (как для гибких армировок), при тех же параметрах подъемных установок;

- снижения трудоемкости технического обслуживания при эксплуатации;

- значительное снижение металлоемкости армировки почти в 2 раза по сравнению с жесткой армировкой ствола;

- незначительное снижение уровня динамических колебаний в системе «сосуд-армировка» до 10кН по сравнению с жесткой армировкой, где динамические нагрузки достигают 50-80кН;

- высокий уровень надежности при работе при значительных горизонтальных нагрузках до 60кН;

- значительное увеличение демпфирующих свойств армировки ствола за счет демпфирования канатами КПП, применения демпферов гасителей колебаний на расстрелах и натяжных устройствах;

- снижение аэродинамического сопротивления ствола до уровня гибкой армировки;

- повышение уровня надежности и безопасности эксплуатации армировки ствола за счет крепления канатов в ограждающем коробе, отсутствия истирания канатов лапами, отсутствия повреждений падающими предметами, коррозии;

- повышение безопасности движения сосудов ввиду отсутствия колеблющийся в стволе отбойных канатов;

- значительно снижение горизонтальных раскачиваний сосудов при их движении по глубине ствола;

- увеличение срока службы прицепных устройств за счет демпфирования колебаний и усовершенствования их конструкции;

- жесткая фиксация натяжных грузов в зумпфе ствола;

- значительного снижения количества, массы и габаритов натяжных грузов в зумпфе;

- снижения глубины зумпфа;

- демпфирования колебаний в канатах с помощью демпфера в зумпфе;

- значительное снижение момента кручения проводников и сосудов в стволе до 0,15 град и ниже при коэффициентах $K \partial=5$ и $K \delta=1.5$ согласно [1];

- значительное снижение моментов кручения проводников за счет применения КДР по сравнению с гибкой армировкой ствола и как следствие 
снижение минимальных зазоров между крепью ствола и сосудом и между сосудами;

- значительное снижение электропотребления в течение всего срока службы ствола, в связи с снижением аэродинамического сопротивления ствола до уровня гибкой армировки, и до 10 раз по сравнению с жесткой армировкой ствола;

- исключение влияния горного давления и неровностей ствола на профиль армировки ствола;

- снижения сечения ствола, за счет использования более рациональных схем армирования ствола.

Внедрение канатно-профильных армировок позволит значительно повысить уровень безопасной эксплуатации армировки вертикального ствола и рентабельности подъемного комплекса в целом.

\section{СПИСОК ЛИТЕРАТУРЫ}

1. «Нормы безопасности на проектирование и эксплуатацию канатных проводников многоканатных подъемных установок», утвержденные Минуглепромом СССР 09.08 .89 и Госгортехнадзором СССР 22.02 .82 и «Нормы безопасности на проектирование и эксплуатацию канатных проводников одноканатных подъемных установок» утвержденные Минуглепромом СССР 09.08.89 и Госгортехнадзором СССР 22.02.82,. - Макеевка - Донбасс: МакНИИ, 1989 - 64стр.

2. Инструкция по эксплуатации стальных канатов в шахтных стволах - М.: Недра, $1989-215$ с. 247стр.

3. Ильин, С.Р. Механика шахтного подъема / С.Р. Ильин, С.С. Ильина, В.И. Самуся.- Днепропетровск: НГУ, 2014 -

4. Пат. 110492 Україна, (51) МПК (2016.01), E21D 7/00. Консольно-демпфіруючий розстріл: / Рубель А.О. // // Бюл. 2016. - №19.

5. Пат. 115478 Україна, (51) MПК Е21D 7/00. Канатно-профрільний провідник армування шахтного стовбура / А.О. Рубель (Україна) // Бюл. - 2017 - 21.

6. Пат. 110518 Україна, (51) МПК (2016.01) E21D 7/00. Дискретне армування стовбура. / А.О. Рубель (Україна) // Бюл. 2016. - №19.

7. Пат. 115967 Україна, (51) МПК (2076.01) Е21D 7/00. Демпфіруючий натяжний пристрій / А.О. Рубель, А.В. Кураєва // Бюл. - 2017. - №9.

8. Волошин, А.И. Армування вертикальних шахтних стволів і методи його вдосконалення / Волошин А.И., Рубель А.А., Рубель А.В. // Геотехнічна механіка: Міжвідомчий збірник наукових праць. - Дніпропетровськ, 2016,. - вип. 126 - С. 137-145.

REFERENCES

1. Ministry of Coal Industry of USSR (1982), 63.21-3.02-82: Normy bezopasnosti na proyektirovaniye $i$ ekspluatatsiyu kanatnykh provodnikov mnogokanatnykh pod"yemnykh ustanovok: normativnyy dokument Gosudarstvennogo komiteta po nadzoru za bezopasnym vedeniyem rabot $v$ promyshlennosti [63.21-3.02-82. Safety standards for the design and operation of cable rope conductors of multi-channel hoisting installations: regulatory document of State Committee for the Supervision of the Safe Work in Industry of USSR], Ministry of Coal Industry of USSR, Makeyevka, SU.

2. State Committee for the Supervision of the Safe Work in Industry (1989), 03-439-02: Instruktsiya po ekspluatatsii stal'nykh kanatov $v$ shakhtnykh stvolakh normativnyy dokument Gosudarstvennogo komiteta po nadzoru za bezopasnym vedeniyem rabot $v$ promyshlennosti [03-439-02. Instruction for operating steel ropes in shafts: regulatory document of State Committee for the Supervision of the Safe Work in Industry of USSR], State Committee for the Supervision of the Safe Work in Industry, Moscow, SU.

3. llyin, S.R., llyin, S.S. and Samusya, V.I. (2014), Mekhanika shakhtnogo pod"yema [Mechanics of mine lifting], National Mining University, Dnepropetrovsk, Ukraine.

4. Rubel, A.O. (2016), Konsol'no-dempfiruyuchyy rozstril [Console-damping shootout], State Register of Patents of Ukraine, Kyiv, Ukraine, Pat. 110492.

5. Rubel, A.O. (2017), Kanatno-profil'nyy providnyk armuvannya shakhtnoho stovbura [Rope-profile reinforcement shaft trunk], State Register of Patents of Ukraine, Kyiv, Ukraine, Pat. 115478.

6. Rubel, A.O. (2016), Dyskretne armuvannya stovbura [Discrete reinforcement of the trunk], State Register of Patents of Ukraine, Kyiv, Ukraine, Pat. 110518.

7. Rubel, A.O. (2017), Dempfiruyuchyy natyazhnyy prystriy [Damping tensioner], State Register of Patents of Ukraine, Kyiv, Ukraine, Pat. 115967.

8. Voloshin, A.I., Rubel, A.A. and Rubel, A.V. (2016) "Reinforcement of vertical shaft shafts and methods for its improvement", Geotekhnicheskaya Mekhanika [Geo-Technical Mechanics], no. 126, pp. 137-145. 
Рубель Андрей Александрович, кандидат технических наук, главный энергетик, Государственное предприятие «Объединенная компания «Укруглереструктуризация», Киев, Украина, AORubel@gmail.com

Рубель Александр Васильевич, магистр, Министерство энергетики и угольной промышленности Украины, Киев, Украина.

\section{About the authors}

Rubel Andrey Aleksandrovich, Candidate of Technical Sciences (Ph.D), Chief Power Engineering Specialist of DP «OK «Ukruglerestrukturizatsiya», Kiev, Ukraine, AORubel @gmail.com

Rubel Alexander Vasilievich, Engineer, Ministry of Power Engineering and Coal Industry of Ukraine, Kiev, Ukraine.

Анотація. Вертикальні стовбури гіничих підприємств - основні виробки, які розраховані на весь термін роботи шахти і довгий час після припинення їі експлуатації. Вони обладнуються армуванням із розстрілами і провідникамі, які використовують рейкові або коробчаті профілі, а також провідникові і відбійні канати.

У основу дослідження покладено задачу пошуку і розробки-робітка нових канатно-профільних армувань для вертикальних стовбурів.

В роботі досліджено існуючі методи армування стовбурів, і розроблено кон-структивні рішення з армування стовбура на основі канатно-профільних провідників з еле-ментами їх кріплення, натягачами і консольними розстрілами. Розробка даних конструктив-них рішень для канатно-профільної армування стовбура дозволить подолати недоліки існуючих жорстких і гнучких армувань і забезпечити: зниження кількості провідників і розстрілів, розташованих по глибині стовбура; вищу швидкість руху і вантажопідйомність посудин; більш тривалий безаварійний термін експлуатації; зниження капітальних витрат внаслідок зменшення діаметра стовбура (за фрактором армування для гнучких армувань); зниження трудомісткості обслуговування і ремонту; значне зниження металоємності армування в порівнянні з жорстким армуванням стовбурів; зниження рівня динамічних коливань в системі «посудина-армування»; збільшення демпфуючих властивостей армування стовбура; зниження аеродинамічного опору стовбура до рівня гнучкою армування; підвищення рівня надійності та безпеки експлуатації армування стовбура; виключення необхідності застосування відбійних канатів; збільшення терміну експлуатації провідників до рівня жорсткого армування стовбура. І, як прямий наслідок, підвищення рентабельності видобутку корисних копалин з більш глибоких горизонтів.

Упровадження канатно-профільних армувань дозволить значно підвищити рівень безпечної експлуатації армувань вертикального стовбура і рентабельності підйомного комплексу в цілому.

Ключові слова: шахтні вертикальні стовбури, канатно-профільні провідники, скіпи, роз-стріли, натяжні пристрої, канати.

Annotation. The vertical shafts of mine enterprises are the basic working of mine, which are counted on all term of work of mine and long time after stopping of its exploitation. They equips by armouring with shooting and explorers, in quality explorers use rail or camber profyles, and also explorer and retreat ropes, are used. Search and development of new rope-type armourings for vertical shafts is fixed in basis of research.

In the work, existing methods for equipping the mine shafts were investigated and constructive solutions were developed for equipping the mine shafts on the basis of rope-profile guides with elements for their fixing by tension devices and cantilevered buntons. Development of the design solutions for rope-profile equipping of the mine shafts will overcome short-comings of existing rigid and flexible shaft equipment and ensure: reduction in the number of the guides and buntons located along the depth of the shaft; higher speed and greater load capacity of skips; longer time period of accident-free operation; reduction of capital costs due to smaller diameter of the shaft (by the factor of shaft equipment for flexible shaft equipment); less working hours of maintenance and repair; significant reduction of metal intensity in the shaft equipment in comparison with the rigid shaft equipment; lower level of dynamic oscillations in the system "skip shaft equipment"; better damping properties of the shaft equipment; reduction of the shaft aerodynamic resistance up to the level of flexible shaft equipment; higher level of reliability and safety of shaft-equipment operation; no need to use balance ropes; longer service life of the guides up to the level of rigid shaft equipment. And, as a direct consequence, higher profitability of mining operations conducted at deep horizons.

Introduction of rope-profyle armourings will allow considerably to promote the level of safe exploitation armourings of vertical shaft and profitability of lifting complex on the whole.

Key words: vertical mine shaft, rope-profile guides, skips, buntons, tension devices, ropes.

Стаття надійшла до редакції 24.02. 2018.

Рекомендовано до друку д-ром техн. наук О.П. Круковським. 